\title{
Some Crucial Problems faced by Manokwari English Teachers
}

\author{
Edi Dwi Riyanto \\ Airlangga University \\ $\&$ \\ Hengki \\ State University of Papua
}

ABSTRACT

The case of Manokwari English teachers shows great challenge. There are at least two main problems: number and quality. The gap between the availability and the need of English teachers at Manokwari is huge. This rarity gives tremendous impact to quality. Some schools just picked any available teachers to teach English regardless the existence of their English background. This paper is aimed at (1) describing the condition of Papua English teacher especially from Manokwari regency, (2) offering some solutions for the condition.

Keywords: teaching problems, number, quality, solutions 


\section{INTRODUCTION}

The newly born Papua Barat province is sure of the importance of improving its hüman resources. In line with the idea, the province stated that, beesides Bahasa Indonesia as the national language, English is its second language (UU OTSUS Bab XVI tentang Pendidikan dan Kebudayaan Pasal 58 ayat 2). Its spirit for progress is undisputable.

However, several big problems are already there. First the demography and geography; Papua is the least populated area and most of its people live far from each other. Worse than that, the it is difficult to connect them. Contact among them are also rare as can be seen from the fact that each tribe, who live relatively in one village, has their own language and can not talk to members from other village well.

The geography and demography leads to difficulties in modern communication. As learning and teaching mainly involve a process of communication, this weakness brings considerable negative impact. Data collection is difficult, telephoning, sending fax, even visiting are not easy jobs.

The third to be noted is financial problem. It is a cliché, yes. But in Manokwari special attention shoud be given especially in dealing with difficult terrain and long distance as related to teachers' living standard.

Others problems could make an endless list. Below are some of our findings in regards to the situations faced by English teachers in Manokwari.

\section{THE EXISTING CONDITION}

From several sources the present condition of english teachers in Manokwari can be described as follows:

a. Few in numbers. From 16 highschools in Manokwari Regency there are only 15

English teachers. It does not mean that there is only one highschool without English teachers. The distribution is uneven. Some highschool have more than one teachers while some others do not have any single teacher. SMAN I, SMK2, and SMA PERS WARMARE each has 4 teachers. More than that, although SMK2 notably has 4 English teachers yet it must considered that three of them do not have any formal English teaching background. They are Theology and Animal Husbandry faculty graduates. Nevertheless, this SMK 2 has English teachers, a condition which is much better than those others which do not have any.

The number becoming less for secondary high school teachers which is only 15 teachers for 30 schools. The case of distribution is the same as what happens to high school teachers, uneven. SMPN 1 has 4 English teachers and some other schools have one or more. More than ten secondary high schools do not have English teacher at all. 
b. Low in quality. It is natural to see that those few number of English teacher would give bad impact to the quality of the personnels, the teaching and learning process, and the result of the English education in general. This realities bring with them a problem of accountability. In micro scope, it is hard for each individual to develop themselves professionally and in macro scope the quality of English teaching and learning is relatively low.

Severe impact of such condition can be observed in many cases. For example; there is no English lesson in secondary high schools which do not have any English teacher. When it comes to Ujian Nasional then unimaginable things happen. Some schools tried to get help from Papua University. They asked the University to teach them all materials. of English lessons from the first, second and third year. This is still much better then other schools which did not know how to get any assistance. Thus a lot of junior high schools had zero preparation to face English UNAS. The consequence is that they have to choose to be honest by writing down the real result of UNAS or to lie. Many schools decided to write 'safe UNAS score'; safe for the schools and safe for students to pass. Two schools tried to write 'true UNAS score'. As a consequences, some students did not pass UNAS. After that people came to the schools to complain and threat since at UNAS 2007 the students were forced to do English test and then they failed the test not because they could not do it but more because they had never been taught English.

In this case we find it almost impossible for many students from Manokwari to comply with UNAS requirements. As David Nunan stated in his book The LearnerCentred Curriculum; A Study in Second Language Teaching (1988) that measurement can be micro or macro in scope UNAS as a tool of measurement fails to do both simply because there is no learning and teaching process. In short, evaluation, measurement, assessment are all impossible just because there is no adequate learning and teaching practice.

At certain level, Papuans become suspicious that it is the intention of Indonesian government to take Papua rich natural resources away while put blind eyes on Papua human resources. Worse, Papuan might think that the situation was conditioned to create weak Papua people to prevent rebellion. In short, the problems surrounding Papua English teachers will quickly become political. Thus, it needs greater attention and efforts to improve it. Otherwise, we are planting a time bomb.

\section{SOME POSSIBLE SOLUTIONS}

In general it can be said that it is necessary to have a comprehensive and down to earth language policy to be applied in Manokwari. To have such a kind of policy needs such a great effort. A. Rappa and L. Wee in language policy and modernity in southeast asia (Malaysia, the Philippines, Singapore and Thailand) (New York: Springer. 2006. pp. 159. said that one of the potentially most frustrating aspects of any work on national language planning and language policy is to balance the broadly political and wider 
social-ethnic-global perspectives with the educational aims of implementation. This is crucial for a deeper appreciation of the range of factors working with and sometimes against declared policies.

The language policy and planning do not necessarily political, yet they need political will very much. Both policy and planning should involve as many aspects as possible such as culture, geography, finance, human resources, and others. The following are some examples we suggest to do in order to help improve the condition of English teachers in Manokwari. The list is open for both discussion and addition.

\section{Recruitment.}

As seen from the above numbers that some school do not even have a single English teachers, recruiting is inevitable. However, the recruitment must be accompanied by a comprehensive policy on human resources especially working condition. Manokwari locality should be considered. This include the geographical and sociocultural condition. An example can be seen from a program sending doctors for remote areas. In this program, those doctors who work in remote areas which are difficult to reach and in many cases are expensive to live are given extra salaries in their payrolls. Some doctors may get more than five millions extra depending on their respective work places. Teachers who work in remote areas should also receive extra benefits to encourage them to stay.

2. Information dissemination. This includes such as materials for teaching, opportunities to get scholarship, and networking. Ausaid has given special quota for East Indonesia to enroll scholarship to Australia but what happened is that the quota is mostly taken by students from Makasar and Manado. The same is also true with scholarship from StuNed, Nederland. As a comparison, from 2000 to 2005 scholarship awardees from StuNed are 63 from Sulawesi and only 2 from Papua.

Papua province government should lobby both Indonesian government and some scholarship provider agents to give quotas for Papua. At the same time facilities for preparation to fulfill the qualification of the scholarships should be provided. Some examples of this are TOEFL or IELTS training and materials.

\section{Training or Professional Development.} recruited.

Training is very important to improve both the existing personnels and the newly

Gabriel Díaz-Maggioli in the Options for Teacher Professional Development written in English Teaching Forum journal Volume 41 Issue 2 states that the language teaching profession is increasingly faced with accountability issues that call for improved teacher development as a means of improving student learning. 
Gabriel then suggested six models of professional development that are focused on the enhancement of teachers' personal and professional situations.

1. Conference. Teachers attend conferences, seminars, or courses as a part of their, tèacher development.

2. Peer Coaching. Colleagues do a voluntary process of observing teaching then sharing perspectives and advice based on that observation.

3. Action Research. Teachers formally ask questions about issues that concern them, refine those questions in light of the contextual constraints in their teaching situation, develop an action plan to answer those questions, implement the plan.

4. Collaborative Study Groups. Collaborative study groups are small groups (not more than 10 participants) of colleagues who get together on a regular, long-term basis (at least once a month for an academic year) to explore issues of teaching and learning. In so doing, they support each other at the personal and professional levels and create new learning opportunities from within the profession.

5. Individual Development Plan. An individual development plan is a structured series of actions aimed at enhancing teacher performance. It should include clear goals and objectives, a schedule of activities for the academic term, a budget if necessary, specification of learning outcomes, and an evaluation.

6. Dialog Journals. Dialog journals offer teachers who cannot join more collegial activities because of constraints of time or distance the chance to keep growing professionally. Dialogue journals are reflective tools that teachers use to chart their actions in the classroom and then exchange with a colleague. The colleague responds in writing to the concerns and questions raised by the teacher, thereby engaging in a pedagogical dialogue with the teacher. Journal entries usually cover specific classroom teaching topics and include analyses of experiences and reactions to classroom events.

Gabriel also stated that the power of the six approaches to professional development outlined above lies in the fact that all of them have as their main interest the needs of the teachers and the desire to improve the quality of learning. By adopting some or all of these approaches for their own professional development, teachers will be better equipped to cope with the challenges of the world ahead, while empowering schools to become better learning institutions.

Another way is through mailing list. This requires internet connection. It can be very cheap, broad, time-saving.

It is understandable that there are many conditions preventing efforts to conduct professional development in Manokwari. However, as Andy Curtis summed up (Essential Teacher 2006) that the reasons to do the professional developments are far more than the reasons not to do it. This is éspecially. important in relation to teaching accountability. 


\section{Funding.}

The government may involve the corporations to get some funding: Using the scheme of CSR or Corporate Social Responsibility the three parties: government, corporations, and community will benefit. CSR is necessary even for the Corporation.

In The Jakarta Post Wednesday 03/21/2007 it is said that the government wanted corporations to apply corporate social responsibility (CSR) programs that empower poor communities throughout the country, rather than simply contributing to charities. The potential fund was about $\mathrm{Rp} 60$ trillion (US $\$ 6.6$ billion) annually that can be earmarked by Indonesia's private and state-owned businesses for their CSR purposes said deputy for poverty alleviation at the Coordinating Ministry for People's Welfare Sujana Royat. That number is higher than the government had allocated in this year's national budget to handling poverty nation-wide which was only $\mathrm{Rp} 51$ trillion.

Manokwari has some big corporations doing business in timber, natural gas, and others. They should work together with the local government to support educational programs in order to alleviate poverty.

\section{Involving other institutions.}

This may includes churches and other NGOs. Some churches have helped mostly elementary schools. It is necessary to encourage them to support more schools both elementary and higher ones. The role of churches can be more than just providing teachers. Churches may take advantage of their international network to initiate, develop and maintain libraries, teachers and students resources, personnel development, and others. NGO may be expected to do the same as churches do.

Institutions like TEFLIN and AsiaTEFL may contribute to the professional development of English teachers in Manokwari for example by inviting them to our conferences and give them partial or full discount or other support.

\section{Intercultural Exchange.}

Intercultural Exchange is more or less a program to develop teacher's professionalism. However, there are some special notes in this point that we discuss it separately.

One important point is about culture and motivation. Junko Kobayashi and Linda Viswat said that motivation is a key issue in teaching a foreign language as well as other subjects. Quoting Gardner (1979) and Williams (1994), Kobayashi and Viswat said that one crucial difference is that teaching a foreign language has a significant impact on the social nature of learners since it sometimes requires learners to adopt new social and cultural behaviors. The Internet TESL Journal, Vol. XIII, No. 11, November 2007.

This is in line with Ramona Tang suggestion that language and culture are inextricably linked. (Tang. 1999). Michael Lessard-Clouston also argued that current L2 and FL teaching is indeed culture teaching. (1997). Both authors agreed that culture should be considered 
The best way to quickly acquire both is by immersion in the target language or culture. In this point it is suggested that there should be more scholarship or apprenticeship done by teachers from Manokwari. This paper is an example of a result of such apprenticeship in which a lecture from Papua University came and stayed at Airlangga University at certain amount of time to share and learn with his colleagues from Airlangga University.

Another way can be done by 'visiting' Manokwari. One or several professional English teachers come and stay in Manokwari and mingle with local teachers. Experience, values, and knowledge can be shared. The 'visiting' teachers will understand more about Mankowari and some Manokwari people will share values or culture with their 'visitors'.

It will take a long time to change culture. That is for sure. However, contact with other cultures resulting in intercultural exchange is one of the most important key for any culture to develop. English teachers in Manokwari could play important roles in improving their community and to do this they need to have much more exposure with. other cultures. In this case, their English competence becomes important tool in opening windows to the world.

An example of this idea is Homestay Program. Lawrence Klepinger quoted Dr. David Wilmoth, Head of the Royal Melbourne Institute of Technology, who said as the following: "Homestay programs are among the most powerful means I know to promote international understanding and goodwill. Households that open their doors to visitors in this way do so for many reasons - interest, curiosity, conviviality among them - but the effect of even short stays can be profound for guest and host alike. The generosity of Japanese families in having an Australian visitor, for example, may lift the scales of prejudice in one day. Such contacts can be lifelong, indeed, intergenerational, as children years later look up faded entries in old address books. The future of international understanding may rest more on such simple acts of kindness than on all the treaties we . can devise." (Klepinger. The Internet TESL Journal, Vol. 1, No. 1, November 1995)

Among the key advantages from this program is cross cultural understanding. Keplinger continued that if a homestay program is to be successful all parties concerned must, first and foremost, be dedicated to the concept of cross-cultural edúcation. They must also believe in the idea of total immersion as one of the best ways to learn another language and culture.

A homestay program can be done nationally, internationally, or both. This program is very important not only to improve cognitive knowledge but also cultural understanding in order to fill the gap of distrust and suspicion among the involved parties. The gap which has long been corrupting our resources. 


\section{CONCLUSION}

The condition of Manokwari English teachers needs great attention from all of us. The dimension is not only educationäl but also cultural and political. Hence, we strongly suggest that contact, communication, sharing, and support should be addressed to our fellow teachers in Manokwari and Papua in general.

\section{BIBLIOGRAPHY}

Díaz-Maggioli Gabriel Options for Teacher Professional Development English Teaching Forum Volume 41 Issue 2

England, Liz. Promoting Effective Professional Development in English Language Teaching(ELT) Vol.36 No 2,April - June 1998 Page 18

Klepinger, Lawrence The Australian/Japanese Homestay Program and its Positive Contribution to Cross-Cultural Understanding The Internet TESL Journal, Vol. 1, No. 1, November 1995 http://iteslj.org/

Kobayashi, Junko and Linda Viswat: Cultural Differences in Motivation to Learn

The Internet TESL Journal, Vol. XIII, No. 11, November 2007 http://iteslj.org/

Lessard-Clouston, Michael. Towards an Understanding of Culture in L2/FL

Education. The Internet TESL Journal, Vol. III, Nó. 5, May 1997 http://itesli.org/

Rappa A. and L. Wee in Language Policy and Modernity in Southeast Asia (Malaysia, the Philippines, Singapore and Thailand) New York: springer. 2006.pp. 159.

Tang, Ramona. The Place of "Culture" in the. Foreign Language Classroom: $A$

Reflection .The Internet TESL Journal, Vol. V, No. 8, August 1999 http://iteslj.orgl

Firms urged to empower people in CSR programs The Jakarta Post Wed, 03/21/2007 